\title{
Vascular Endothelial Growth Factor A
}

National Cancer Institute

\section{Source}

National Cancer Institute. Vascular Endothelial Growth Factor A. NCI Thesaurus. Code C20450.

Vascular endothelial growth factor A (232 aa, 27 kDa) is encoded by the human VEGFA gene. This protein plays a role in both cell proliferation and angiogenesis. 